JKM (Jurnal Kebidanan Malahayati),Vol 7,No.3.Juli 2021,

ISSN (Print) 2476-8944 ISSN (Online) 2579-762X, Hal 371-375

\title{
AROMATERAPI CITRUS AURANTIUM MEMPENGARUHI KECEMASAN PERSALINAN KALA 1 FASE AKTIF
}

\author{
Dina Octavia ${ }^{1 *}$, Dainty Maternity², Yuli Yantina², Dewi Yuliasari² \\ ${ }^{1}$ Rumah Sakit Ibu dan Anak Puri Betik Hati Kota Bandar Lampung \\ 2,3Prodi DIV Kebidanan Universitas Malahayati \\ 4Prodi DIII Kebidanan Universitas Malahayati \\ *Korespondensi email: dinaoctavia816@gmail.com
}

\section{ABSTRACT CITRUS AURANTIUM AROMATHERAPY AFFECTS LABOR ANXIETY LEVEL ONE STEP ACTIVE}

Background: Anxiety is a disturbance in feelings characterized by feelings of fear or worry that are deep and ongoing. Anxiety is the most common female psychological response to childbirth. Aromatherapy is the use of scents with essential oils that promote a sense of calm and help reduce anxiety.

The purpose of this study was to determine the effect of Citrus aurantium aromatherapy on the level of anxiety during the first stage of active labor at RSIA Puri Betik Hati, Bandar Lampung City.

Method: This type of research is quantitative, with a Quasi Experiment Design research design using a Two Group Pre-Post Test Design. The sampling technique used is Non Probability Sampling with Accidental Sampling technique. This study used 60 research samples, divided into 2 groups, namely 30 mothers in the intervention group and 30 mothers in the control group. Measurement of anxiety levels using the Hamilton Anxiety Rating Scale (HAM-A) measuring instrument, where data collection uses observation sheets and SOPs. Analysis of the data used is the Independent Sample T-Test.

Results: From the results of the research conducted by the authors, it is known that the average value of the level of labor anxiety in the intervention/experiment group (Citrus aurantia Aromatherapy) was 14.93, while in the control group the average level of labor anxiety was 28.63 the significance value is $0.000, P$ value $(0.05)$ means "There is an effect of Citrus aurantium aromatherapy on the level of anxiety in the first stage of active labor.

Conclusion: Observation results showed that respondents who were given Citrus aurantia aromatherapy showed a significant decrease in anxiety with mild to no anxiety levels.

Suggestions It is expected that health workers will provide counseling to mothers who will give birth at a risky age, basic education level, parity primipara and grande multipara, to anticipate anxiety in mothers and provide information about preparation for childbirth and how to control changes in maternal psychology so that they can anticipate anxiety during the delivery process .

Keywords: Anxiety of labor, Citrus aurantium Aromatherapy.

\section{ABSTRAK}

Latar Belakang: Kecemasan adalah gangguan dalam perasaan yang ditandai dengan perasaan ketakutan atau kehawatiran yang mendalam dan berkelanjutan. Kecemasan adalah respon psikologis wanita yang paling umum terhadap persalinan. Aromaterapi adalah penggunaan aroma dengan minyak essensial yang meningkatkan rasa tenang dan membantu mengurangi kecemasan.

Tujuan penelitian : Untuk mengetahui pengaruh aromaterapi Citrus aurantium terhadap tingkat kecemasan persalinan fase aktif kala 1 di RSIA Puri Betik Hati Kota Bandar Lampung.

Metode penelitian: Jenis penelitian ini adalah kuantitatif, dengan rancangan penelitian Quasi Eksperimen Design menggunakan rancangan Two Group Pre-Post Test Design. Teknik sampling yang digunakan adalah Non Probability Sampling dengan teknik Accidental Sampling. Penelitian ini menggunakan 60 sampel penelitian, dibagi menjadi 2 kelompok yaitu 30 ibu pada kelompok intervensi dan 30 ibu pada kelompok kontrol. Pengukuran tingkat kecemasan menggunakan metode alat ukur Hamilton Anxiety Rating Scale (HAM-A), dimana pengumpulan data menggunakan lembar observasi dan SOP. Analisa data yang digunakan adalah Uji T Sampel Independen.

Hasil: Dari hasil penelitian yang dilakukan oleh penulis, diketahui bahwa nilai rata-rata tingkat kecemasan persalinan pada kelompok Intervensi/eksperimen (Aromaterapi Citrus aurantium) adalah sebesar 14.93, 
sementara pada hasil kelompok kontrol rata-rata rata-rata tingkat kecemasan persalinan sebesar 28.63 dan nilai signifikansinya sebesar $0.000, \mathrm{P}$ value $\leq \mathrm{a}(0,05)$ artinya "Ada pengaruh aromaterapi Citrus aurantium terhadap tingkat kecemasan persalinan fase aktif kala 1

Kesimpulan: Hasil observasi didapatkan bahwa responden yang diberikan aromaterapi Citrus aurantium menunjukkan penurunan kecemasan yang signifikan dengan tingkat kecemasan ringan hingga tidak ada kecemasan.

Saran Diharapkan tenaga kesehatan melakukan konseling kepada ibu yang akan bersalin dengan umur yang berisiko, tingkat pendidikan dasar, paritas primipara dan grande multipara, untuk mengantisipasi kecemasan pada ibu serta memberikan informasi mengenai persiapan persalinan dan cara mengendalikan perubahan psikologi ibu sehingga dapat menganisipasi kecemasan selama proses persalinan.

Kata Kunci :Kecemasan persalinan, Aromaterapi Citrus aurantium.

\section{PENDAHULUAN}

Persalinan merupakan proses pergerakan keluarnya janin, plasenta, dan membrane dari dalam rahim melalui jalan lahir. Proses ini berawal dari pembukaan dan dilatasi serviks sebagai akibat kontraksi uterus dengan frekuensi, durasi, dan kekuatan yang teratur. Mula-mula kekuatan yang muncul kecil, kemudian terus meningkat sampai pada puncaknya pembukaan serviks lengkap sehingga siap untuk pengeluaran janin dari Rahim ibu (Rohani, 2011). Tahapan persalinan terbagi menjadi 4 kala yaitu: kala I (pembukaan), kala II (pengeluaran janin), kala III (pelepasan plasenta), dan kala IV (kala pengawasan lobservasi/pemulihan) (Jenny, 2013).

Dalam perjalanan persalinan kala 1 ibu mengalami gangguan psikologi yaitu kecemasan dimana menurut Mc Nerney and Grenberg menyebutkan kecemasan merupakan sebagai reaksi fisik, mental, kimiawi dari tubuh terhadap situasi yang menakutkan, mengejutkan, membingungkan, membahayakan, dan merisaukan seseorang (Sumarah, 2008).

Di Indonesia terdapat 373.000 .000 ibu hamil pada tahun 2016, yang mengalami kecemasan dalam menghadapi persalinan sebanyak 107.000 .000 orang $(28,7 \%)$. Seluruh populasi di pulau jawa terdapat 679.765 ibu hamil, yang mengalami kecemasan dalam menghadapi persalinan 355.873 orang (Depkes RI, 2017). Berdasarkan data Profil Kesehatan Provinsi Lampung, terdapat 113.976 ibu hamil dengan 9.897 orang $(8,68 \%)$ mengalami kecemasan dalam menghadapi persalinan (Dinas Kesehatan, 2015).

Salah satu terapi nonfarmakologi untuk mengurangi nyeri persalinan dan kecemasan yaitu dengan aromaterapi. Aromaterapi Citrus aurantium merupakan sebuah terapi non farmakologis untuk mengurangi tingkat kecemasan ibu yang melahirkan kala 1 (Koensoemardiyah, 2009).
Aromaterapi Citrus aurantium belum pernah digunakan untuk mengatasi tingkat kecemasan pada persalinan kala 1 di RSIA Puri Betik Hati. Sehingga peneliti tertarik untuk melakukan penelitian tentang pengaruh aromaterapi Citrus aurantium terhadap tingkat kecemasan persalinan fase aktif kala I. Tujuan peneltian untuk mengetahui pengaruh aromaterapi Citrus aurantium terhadap tingkat kecemasan persalinan fase aktif kala $1 \mathrm{di}$ RSIA Puri Betik Hati Kota Bandar Lampung.

\section{METODOLOGI PENELITIAN}

Jenis penelitian ini adalah kuantitatif, dengan rancangan penelitian Quasi Eksperimen Design menggunakan rancangan Two Group Pre-Post Test Design. Teknik sampling yang digunakan adalah Non Probability Sampling dengan teknik Accidental Sampling. Penelitian ini menggunakan 60 sampel penelitian, dibagi menjadi 2 kelompok yaitu 30 ibu pada kelompok intervensi dan 30 ibu pada kelompok kontrol. Pengukuran tingkat kecemasan menggunakan metode alat ukur Hamilton Anxiety Rating Scale (HAM-A), dimana pengumpulan data menggunakan lembar observasi dan SOP. Analisa data yang digunakan adalah Uji T Sampel Independen.Variabel bebas yang digunakan pada penelitian ini yaitu pemberian aromaterapi Citrus aurantium. Sementara variabel terikat dalam penelitian ini yaitu tingkat kecemasan fase aktif kala satu.

Analisa univariat adalah menjelaskan dan mendiskripsikan karakteristik setiap variabel penelitian (Notoatmodjo, 2018). Analisa univariat dalam penelitian ini adalah data ibu inpartu fase aktif kala 1. Data kategorik menggunakan presentase dan frekuensi sedangkan numerik menggunakan descriptive mean, standar deviasi dan nilai maksimum dan nilai minimum maksimum.

Analisa data bivariat adalah analisa yang dilakukan terhadap dua variabel yang di duga berhubungan atau berkolerasi (Notoatmodjo, 2018). 
JKM (Jurnal Kebidanan Malahayati),Vol 7,No.3.Juli 2021,

ISSN (Print) 2476-8944 ISSN (Online) 2579-762X, Hal 371-375

Perhitungan dilakukan dengan komputer menggunkan aplikasi SPSS-22 dengan Independent sample t-test (Notoatmodjo, 2018).

\section{HASIL PENELITIAN}

Berdasarkan tabel 1 dapat disimpulkan bahwa dari 30 responden penelitian, diperoleh hasil nilai mean atau nilai rata-rata tingkat kecemasan persalinan fase aktif kala 1 di RSIA Puri Betik Hati Kota Bandar Lampung Tahun 2019, sebelum intervensi diberikan (pre-test aromaterapi Citrus aurantium) adalah sebesar 28.03 yang artinya tingkat kecemasan sedang, dengan nilai minimum tingkat kecemasan sebesar 18 (kecemasan ringan) dan nilai maximum 36 (kecemasan berat), serta nilai standar deviasi sebesar 5.223. Sedangkan, nilai rata-rata tingkat kecemasan persalinan sesudah Intervensi diberikan (post-test) adalah sebesar 14.93 yang artinya tingkat kecemasan ringan, dengan nilai minimum kecemasan sebesar 6 (tidak ada kecemasan) dan nilai maximum 24 (kecemasan sedang), serta nilai standar deviasi sebesar 5.439. Dilihat dari nilai rata-rata pada kelompok intervensi ini mengalami penurunan.

Tabel 1.

Rata-rata tingkat kecemasan sebelum dan sesudah menerima Aromaterapi Citrus aurantium selama persalinan fase aktif kala 1, dan kelompok control di RSIA Puri Betik Hati Kota Bandar Lampung Tahun 2019.

\begin{tabular}{lcccccc}
\hline \multirow{2}{*}{$\begin{array}{l}\text { Persalinan fase } \\
\text { aktif kala 1 }\end{array}$} & Variabel & $\mathbf{N}$ & Min. & Max. & Mean & Std. Deviation \\
\cline { 2 - 7 } & Pre-test & 30 & 18 & 36 & 28.03 & 5.223 \\
& Post-test & 30 & 6 & 24 & 14.93 & 5.439 \\
\hline \multirow{2}{*}{ Kelompok } & Variabel & $\mathbf{N}$ & Min. & Max. & Mean & SD \\
\cline { 2 - 7 } control & Pre-test & 30 & 18 & 35 & 28.10 & 4.730 \\
& Post-test & 30 & 18 & 40 & 28.63 & 6.641 \\
\hline
\end{tabular}

\section{Analisis Bivariat}

Berdasarkan tabel 2 diatas didapatkan hasil nilai rata-rata tingkat kecemasan persalinan pada kelompok Intervensi/eksperimen (Aromaterapi Citrus aurantium) adalah sebesar 14.93 yang artinya tingkat kecemasan ringan, sementara pada kelompok kontrol rata-rata tingkat kecemasan persalinan sebesar 28.63 yang artinya tingkat kecemasan berat, dengan demikian secara deskriptif statis dapat disimpulkan ada perbedaan rata-rata tingkat kecemasan persalinan antara kelompok eksperimen dan kelompok kontrol.
Artinya penurunan tingkat kecemasan persalinan yang diberikan intervensi dengan Aromaterapi Citrus aurantium lebih rendah dengan nilai rata-rata 14.93 (Kecemasan Ringan) sedangkan kelompok kontrol dengan nilai rata-rata 28.63 (Kecemasan Berat). Berdasarkan tabel output "Uji Sampel Independen T-test" pada nilai signifikansi sebesar 0.000 , $\mathrm{P}$ value $\leq \mathrm{a}(0,05)$ artinya $\mathrm{Ho}$ ditolak dan $\mathrm{Ha}$ diterima yang berarti "Ada pengaruh aromaterapi Citrus aurantium terhadap tingkat kecemasan persalinan fase aktif kala 1 di RSIA Puri Betik Hati kota Bandar Lampung".

Tabel 2.

Pengaruh Aromaterapi Citrus aurantium terhadap tingkat kecemasan persalinan fase aktif kala 1 di RSIA Puri Betik Hati Kota Bandar Lampung Tahun 2019.

\begin{tabular}{lccccc}
\hline $\begin{array}{l}\text { Hasil tingkat kecemasan } \\
\text { persalinan }\end{array}$ & N & Mean & $\begin{array}{c}\text { Std. } \\
\text { Deviation }\end{array}$ & $\begin{array}{c}\text { Std. Error } \\
\text { Mean }\end{array}$ & P value \\
\hline $\begin{array}{l}\text { Kelompok Intervensi (Aromaterapi } \\
\begin{array}{l}\text { Citrus aurantium) } \\
\text { Kelompok kontrol }\end{array}\end{array}$ & 30 & 14.93 & 5.439 & 0.993 & 0.000 \\
\hline
\end{tabular}

\section{PEMBAHASAN}

Berdasarkan tabel 1 diketahui bahwa dari 30 responden penelitian, diperoleh hasil nilai mean atau nilai rata-rata tingkat kecemasan persalinan fase aktif kala 1 di RSIA Puri Betik Hati Kota Bandar Lampung Tahun 2019, sebelum atau pre-test kelompok kontrol adalah sebesar 28.10 yang artinya tingkat kecemasan berat, dengan nilai minimum tingkat kecemasan sebesar 18 (kecemasan ringan) dan nilai maximum sebesar 35 (kecemasan berat), serta nilai standar deviasi sebesar 4.730. Sedangkan, nilai rata-rata intensitas 
nyeri post-test untuk kelompok kontrol adalah sebesar 28.63 yang artinya tingkat kecemasan berat, dengan nilai minimum tingkat kecemasan sebesar 18 (kecemasan ringan) dan nilai maximum sebesar 40 (kecemasan berat), serta nilai standar deviasi sebesar 6.641. Dilihat dari nilai rata-rata pada kelompok kontrol ini tingkat kecemasan tidak mengalami penurunan.

Berdasarkan tabel 2 diatas didapatkan hasil nilai rata-rata tingkat kecemasan persalinan pada kelompok Intervensi/eksperimen (Aromaterapi Citrus aurantium) adalah sebesar 14.93 yang artinya tingkat kecemasan ringan, sementara pada kelompok kontrol rata-rata tingkat kecemasan persalinan sebesar 28.63 yang artinya tingkat kecemasan berat, dengan demikian secara deskriptif statis dapat disimpulkan ada perbedaan rata-rata tingkat kecemasan persalinan antara kelompok eksperimen dan kelompok kontrol. Artinya penurunan tingkat kecemasan persalinan yang diberikan intervensi dengan Aromaterapi Citrus aurantium lebih rendah dengan nilai rata-rata 14.93 (Kecemasan Ringan) sedangkan kelompok kontrol dengan nilai rata-rata 28.63 (Kecemasan Berat). Berdasarkan tabel output "Uji Sampel Independen T-test" pada nilai signifikansi sebesar $0.000, \mathrm{P}$ value $\leq \mathrm{a}(0,05)$ artinya $\mathrm{Ho}$ ditolak dan $\mathrm{Ha}$ diterima yang berarti "Ada pengaruh aromaterapi Citrus aurantium terhadap tingkat kecemasan persalinan fase aktif kala 1 di RSIA Puri Betik Hati kota Bandar Lampung".

\section{SIMPULAN}

Nilai rata-rata tingkat kecemasan sebelum intervensi adalah 28.03 (kecemasan berat) dan sesudah intervensi adalah 14.93 (kecemasan ringan) dengan menggunakan aromaterapi Citrus aurantium selama persalinan fase aktif kala $1 \mathrm{di}$ RSIA Puri Betik Hati Kota Bandar Lampung, nilai rata-rata tingkat kecemasan sebelum/pre-test adalah 28.10 (kecemasan berat) dan sesudah/posttest adalah 28.63 (kecemasan berat) pada kelompok kontrol selama persalinan fase aktif kala 1 di RSIA Puri Betik Hati Kota Bandar Lampung, dan adanya pengaruh aromaterapi Citrus aurantium terhadap tingkat kecemasan persalinan fase aktif kala 1 di RSIA Puri Betik Hati Kota Bandar Lampung, dengan hasil T-test pada nilai signifikansi P-value sebesar $0.000 \leq a(0,05)$.

\section{SARAN}

Diharapkan tenaga kesehatan melakukan konseling kepada ibu yang akan bersalin dengan umur yang berisiko, tingkat pendidikan dasar, paritas primipara dan grande multipara, untuk mengantisipasi kecemasan pada ibu serta memberikan informasi mengenai persiapan persalinan dan cara mengendalikan perubahan psikologi ibu sehingga dapat menganisipasi kecemasan selama proses persalinan.

Hasil penelitian ini diharapkan dapat menjadi bahan referensi guna melakukan penelitian yang sama, dan peneliti selanjutnya diharapkan dapat meneliti lebih lanjut variabel lain dengan menggunakan aromaterapi jenis lainnya seperti lavender, lemon, peppermint dan lain sebagainya serta memodifikasi cara pemberian aromaterapi dengan beberapa teknik inhalasi seperti menggunakan botol semprot, alat diffuser atau yang lebih praktis dengan inhalasi telapak tangan, rendam air hangat dan lain sebagainya.

\section{DAFTAR PUSTAKA}

Arikunto, Suharsimi. (2014). Prosedur Penelitian. Jakarta: Rineka Cipta.

Dinas Kesehatan. (2015), Profil Kesehatan Provinsi Lampung Tahun 2015. Lampung: Pemerintah Provinsi Lampung.

Hawari, Dadang. (2016). Manajemen Stress Cemas dan Depresi. Jakarta: FKUI.

Judha, Mohamad. (2012). Teori Nyeri dan Nyeri Persalinan. Yogyakarta: Nuha Medika.

Khakpor, Shahrzad et al. (2014). Effect of Citrus Aurantium L. Essential Oil and Haloperidol on Anxiety in Male Mice. World Journal of Neuroscience, $\quad 4$ : 427-433. http://dx.doi.org/10/4236/wjns.2014.45047.

Koensoemardiyah. (2009). Aromaterapi untuk Kesehatan, Kebugaran, dan kecantikan. Yogyakarta: Andi.

Kusuma, Kelana. (2015). Metode Penelitian Keperawatan. Jakarta Timur: Trans Info Media.

Leite, Mariana P. et al. (2008). Behavioral effect of essential oil of Citrus aurantium L. inhalation in Rats. Brazilian Journal of Pharmacognosy, 18: 661-666.

Leveno, Kenneth J. (2009). Obstetri Williams: Panduan Ringkas Edisi 21. Jakarta: EGC.

Manuaba. (2012). IImu Kebidanan, Penyakit Kandungan, dan KB. Jakarta: EGC.

Maryunani, Anik. (2010). Nyeri Dalam Persalinan Teknik dan cara Penanganannya. Jakarata: TIM.

Namazi, Masoumeh et al. (2014). Aromatherapy With Citrus Aurantium Oil and Anxiety During the First Stage of Labor. Iran Red Crescent Med J, 16(6): e18371. http://dx.doi.org/10.5812/ircmj.18371. 
JKM (Jurnal Kebidanan Malahayati),Vol 7,No.3.Juli 2021,

ISSN (Print) 2476-8944 ISSN (Online) 2579-762X, Hal 371-375

Notoatmodjo, Soekidjo. (2018) Metode Penelitian Kesehatan. Jakarta: Rineka Cipta.

Prawihardjo. (2008). IImu Kebidanan. Jakarta: Yayasan Bina Pustaka.

Prawihardjo. (2009). Ilmu Kebidanan. Jakarta: Yayasan Bina Pustaka.

Kemenkes RI. (2016). Profil Kesehatan Indonesia Tahun 2015. Jakarta: Kementerian Kesehatan Republik Indonesia.

Rohani. (2011). Asuhan Kebidanan pada Masa Persalinan. Jakarta: Salemba Medika.

Sumarah. (2008). Perawatan Ibu Bersalin. Yogyakarta: Fitramaya.
Sumarah. (2009). Perawatan Ibu Bersalin. Yogyakarta: Fitramaya.

Sugiyono. (2017). Metode Penelitian Pendidikan. Bandung: Alfabeta.

Sulistyawati, Ari. (2011). Asuhan Kebidanan pada Masa Kehamilan. Jakarta: Salemba Medika.

Sondakh, J.S. Jenny. (2013). Asuhan Kebidanan Persalinan dan Bayi Baru Lahir. Jakarta: Erlannga.

Stuart. (2016). Keperawatan Kesehatan Jiwa. Elsevier Singapore Pte Ltd. 